\title{
The Impact of the Vision 2020 Umurenge Program Direct Support Project on Households: A Case Study of Mwendo Sector in Ruhango District in Rwanda
}

\author{
Silas Bahigansenga ${ }^{1}$ and Jean de Dieu Hakizimana ${ }^{2}$ \\ ${ }^{1}$ School of Business and Economics, Mount Kenya University, \\ Kigali, P.O. Box 5826 Rwanda \\ ${ }^{2}$ School of Business and Economics, Mount Kenya University, \\ Kigali, P.O. Box 5826 Rwanda
}

\begin{abstract}
The Government of Rwanda in collaboration with development partners and the non-government organization has initiated a Vision 2020 Umurenge Program direct support project on households under the National Vision 2020. The study assessed the impact of the Vision 2020 Umurenge Program direct support project on households. The research design of the study was descriptive with qualitative and quantitative approaches. The simple random sampling technique and stratified random sampling technique were used to select respondents. The sample size included 244 respondents. The study showed that there is a statistically significant relationship between the direct support project and social-economic development of the households. As a result, the study found out that the majority of the households struggle with the increasing cost of living. The study recommended that evaluation time needs to be increased to a period of more than six months in order to give them more time to uplift their household.
\end{abstract}

Keywords: Vision 2020 Umurenge Program, Economic productivity, Household development, Self-reliance

\section{Introduction}

Despite significant efforts to eradicate poverty over the last decade, Rwanda remains classified as one of Africa's poorest countries (MINALOC, 2009). Poverty prevails, although at a decreasing rate Per capita income was estimated at \$US 281 in 2006, $56.9 \%$ of the Rwandan population was classified poor in the same year, while $36.9 \%$ were Surviving in conditions of extreme poverty. Multiple factors contribute to this situation, including a turbulent history (1994 genocide), low agricultural productivity, leading to poor yields for major crops, population pressure on arable land, poor agricultural marketing in rural areas, rural unemployment, and lack of savings and investment in rural households and weak environmental conservation practices.

Globally, the number of people in absolute poverty has been in decline for around 25 years, yet in Africa, it is still increasing. The dare of poverty reduction in Africa is of a different order from that elsewhere and will involve different approaches (Collier, 2007). According to the Brandt (2006), hundreds of millions of people in the poorer countries are preoccupied solely with survival and elementary needs. For them work is frequently not available or, when it is, the pay is low and conditions often barely tolerable. Thus, reducing poverty in rural areas, and hunger in both rural and urban areas, will depend heavily on sustainable community development.

Direct support is the third component of VUP (Vision 2020 Umurenge Program) which aims to improve access to social services or to provide for landless households with no members qualifying for public works or credit packages, such unconditional support seeks to expand health and education coverage as well as to encourage the development of "appropriate" skills handicraft or social service activities. This component also includes social assistance for extremely vulnerable people.

It is a household-based cash transfer poverty project focused on moving people out of extreme poverty in a sustainable way. The "poor must find ways to convert their assets and talents (e.g. skills and productive labour, financial capital, land, nutrition, health) into income, and to release their productive capacity" (MINALOC, 2009). It targets a group of people without land and so the capacity to work. Those with very few assets and productive skills and will be, understandably, much more 
cautious and take fewer risks than other extremely poor people.

According to MINALOC (2009), the poor and extremely poor households require an integrated approach that combines activities in a way that addresses their needs. Cash transfers constitute an effective mechanism for providing resources to poor households if essential goods are available on the market but the poor do not have enough money to purchase them. If the amount of the transfer is enough to cover expenditure deficits and is predictable, a cash transfer can also provide a solid base to reduce poverty by encouraging households to develop their skills and take risks and adopt other livelihood support activities.

The direct support cash transfer is premised on the rationale that many of the poorest can be helped to help themselves meet survival and livelihood protection needs and some will have the potential to eventually graduate out of poverty if given the right support (an appropriate mix of interventions properly sequenced) and the will and capacity to succeed.

The VUP Direct Support income transfer aims to combine an unconditional cash transfer with a core complementary package of training, sensitization and savings to produce an integrated response. Households will also possibly have access to modest amounts of credit, provided they qualify and it is available. In this way, the productive potential of the poor can potentially be unleashed leading to social-economic transformation in their lives.

It is from this background therefore that this study intends to assess the impact of the VUP Direct Support projects with regard to improving their productive potential and promoting self-sufficient household. The study focused on Mwendo in Ruhango District.

Until very recently, households in Rwanda that fall into the category of extremely poor have relied on the assistance of other household and village members and the provision of external food and other aid for their survival. This assistance helpful though, can be said to be ad-hoc with no reliability guarantee of fully covering the survival needs of recipient households while fostering a culture of selfsustainability or self-sufficiency.

Direct Support project was adopted as a more strategic approach to assisting the extremely poor of households in a reliable and sufficient manner to allow them to focus on possible options for helping themselves rather than constantly relying on external support. It is an attempt to provide a regular level of income to raise these households out of extreme poverty and to give them the opportunity to explore possibilities for becoming self-sufficient in the longer term.

Its complementary elements of provision of training, voluntary savings and possibly modest amounts of credit for qualifying households were expected to graduate some households from the project and become either participant in public works or fully or partially self-sufficient.

However, while some previously poor households have been able to graduate to an economically self-sufficient level, there remains an arguably large number who are far from this reality. Moreover, there is a perception among some recipients of Direct Support (extremely poor households) that it is an entitlement which is counter-productive to the premise that direct support should not be a form of economic dependency.

The settlers of the Ruhango district were practising poor and or traditional ways of doing agriculture in their livelihood, where the majority of Ruhango District lives under poverty line even for limited plots. Their capacity was very limited to boost their agricultural practice and production, they depend mainly on agriculture for surviving and remain in the most vulnerable and marginalized people in Rwanda.

It is from this background that this study was undertaken to assess the impact of the 2020 VUP Direct support project on the social-economic development of the poor households in Rwanda. The study used the case study of Mwendo sectors in Ruhango District. It was hoped that the study should highlight some anomalies that hamper the effectiveness of Direct Support project from enhancing economic productivity and promoting self-sufficiency of poor households in Rwanda.

The general objective of this study is to find out how direct support project influence socio-economic development in Mwendo Sector in Ruhango District in the years 2015 to 2018. The specific objectives of this research is to assess the process of selecting the beneficial households of the direct support, investigate the economic activities the households performed as a result of direct support, to assess the payment process and duration of delivery of the direct support to households, and to investigate the effect of training and access to credit on the household's economic productivity and self-reliance.

\section{Review of Literature}

According to Maslow's "Hierarchy of Needs Theory" and the "Theory of Human Motivation", people aim to meet basic needs, they seek to meet successively higher needs in the form of a pyramid. The Maslow's Hierarchy of Needs has often been represented in a hierarchical pyramid with five levels (lower-order needs) are considered psychological needs, while the top level of the pyramid is considered growth needs (Maslow, 1970). This study considers the theory to be relevant because we are discussing ways used to attend to the needs of the poor people in society. 
However, this theory has been criticized in the sense that there is vagueness is what is considered a 'deficiency', citing that what is deficient for one is not necessarily a deficiency for another. Secondly, there seem to be various explanations that frequently occur. For example, some people often risk their safety to rescue others from danger.

The theoretical debate about benefiting the poor has traditionally been dictated by two schools of thought. One cohort believes that the best possible way to execute any poverty reduction intervention is by "identifying" those in need and then directing the entire resource pool towards them. The opposing view prefers universal programs that are extended to all, irrespective of the level of poverty, but offer benefits that in theory end up benefiting the poor disproportionately (Besley and Kanbur, 1991).

Moreover, political economy considerations of balancing the needs of the poor and the vested interests of the middle and upper socioeconomic strata can undermine the theoretical advantage of resource efficiency in targeted interventions (Besley and Kanbur, 1991; Besley and Coate, 1997. A failure to account for these concerns inevitably leads to one of the two types of errors associated with targeting. These include the error of under coverage or exclusion (type I) where some of the poor are not reached and the error of leakage or inclusion (type II) in which the non-poor those outside the target group receive direct benefits from the program (Hansen, Kelley and Weisbrod, 1970).

\subsection{Direct support}

Direct support is concerning of assisting an individual with a disability to lead a self-directed life and contribute to the community, assists with activities of daily living if needed, and encourages attitudes and behaviours that enhance community inclusion. People who have developmental and intellectual deficiencies need a direct support professional (DSP) to train them and make their lives better. Being a DSP is challenging and rewarding at the same time. Challenges may include lack of cooperation from your patients, lack of enough facilities and poor response to training. Rewards may include gaining more skills and experience in professional support and having a sense of satisfaction and fulfilment resulting from successful training programs (NISR, 2015).

\subsection{Project}

A project is a temporary endeavour undertaken to create a unique product or service (Turner and Müller, 2003). Temporary means that every project has a definite beginning and a definite ending. Unique means that the product or service is different in some distinguishing way from all similar products and services. The word project is derived from Latin where "pro" means "forward" and "jacere" means "throw". Thus the original meaning of project is something that in a figurative sense has been thrown forward, a proposal. The meaning has gradually been extended to include the process of realizing the proposal and the people who perform the realization.

\subsection{Socio-economic and Development}

It is the social science that studies how economic activity affects and is shaped by social processes. In general, it analyses how societies progress, stagnate or regress because of their local or regional economy, or the global economy. Societies are divided into 3 groups: social, cultural and economic (Henrich, Boyd, Bowles, and Camerer, 2005).

According to Todaro (2005), development refers to development as a multi-dimensional process involving the reorganization and reorientation of the entire economic and social systems. Nevertheless, a careful analysis reveals that each level, a country can have different definitions of development.

\subsection{Conditional Cash Transfers as opposed to unconditional Cash Transfers}

According to The Economist (2013), for decades, it was thought that the poor needed almost everything done for them and that experts knew best what this was. Few people would trust anyone to spend $\$ 1,000$ responsibly. Instead, governments, charities and development banks built schools and hospitals, roads and ports, irrigation pipes and electric cables. And they set up big bureaucracies to run it all. However, from around 2000, a different idea started to catch on: governments gave poor households small stipends to spend as they wished on the condition that their children went to school or visited a doctor regularly.

These so-called "CCTs" (conditional cash transfers) appeared first in Latin America and then spread around the world. They did not replace traditional aid but had distinctive priorities, such as supporting individual household budgets and helping women (most payments went to mothers). They were also cheap to run.

Projects such as Give Directly in Kenya are the latest elaboration of these ideas. Their designers saw that CCTs had boosted household incomes, and asked whether extra conditions, such as mandatory school attendance, were necessary. They also argued that, if CCTs were cheap to run, UCTs (unconditional cash transfers) would be cheaper still.

Now enough of these programs are up and running to make a first assessment. Early results are encouraging: giving money away pulls people out of poverty, with or without conditions. Recipients of unconditional cash do not blow it on booze and brothels, as some feared. Households can absorb a surprising amount of cash and put it to good use. But 
conditional cash transfers still seem to work better when the poor face an array of problems beyond just a shortage of capital.

The same paper maintains that a trial in Vietnam in 2006 gave one-off handouts to 550 households; two years later, local poverty rates had fallen by 20 percentage points. The scheme was dubbed "cash for coffins" after elderly recipients spent the money on their funeral arrangements to save their children the expense.

Furthermore, a different scheme is reported to have been running in northern Uganda for four years. The government gives lump sums of around $\$ 10,000$ to groups of 20 or so young people who club together to apply. Recipients spent a third of the money learning a trade (such as metalworking or tailoring) and much of the rest on tools and stock. They set up enterprises and work longer hours in their new trades. Average earnings rose by almost $50 \%$ in four years.

This scheme has a condition: applicants must submit a business plan. But it highlights the virtues of no-strings grants. They work when lack of money is the main problem. The people who do best are those with the least to start with, in Uganda that especially means poor women. In such conditions, the schemes provide better returns than job-training programs that mainstream aid agencies prefer. Most importantly, they even do better than secondary education, which pushes up wages in poor countries by $10-15 \%$ for each extra year of schooling. This may be because recipients know what they need better than donors do which is a core advantage of no-strings schemes. They also outscore conditional transfers, because some families eligible for these fail to meet the conditions through no fault of their own if they live too far from a school, for instance.

Also, The Economist (2013) reports a smaller program in Ghana which offers a contrast to the Ugandan scheme by boosting training and enterprise growth. The Ghanaian program gave small sums (\$120) to a random selection of business owners, some unconditionally, some requiring the owner to buy something for his or her firm. The conditional benefits proved more useful: profits at firms that got such payments were twice as high after three years as at firms that got cash with no strings attached. In contrast to the Ugandan experience, the women who started with the least (whose firms had the lowest profits) did worst. The big Households were women whose profits were high at first. In Ghana, just handing over money was not the best way to help firms.

\subsection{Direct support for small projects/startups}

The Economist (2013) reports that a trial cash transfer in Vietnam in 2006 gave one-off handouts to 550 households; two years later, local poverty rates had fallen by 20 percentage points. The scheme was dubbed "cash for coffins" after elderly recipients spent the money on their funeral arrangements to save their children the expense. Also, in northern Uganda, the government gives lump sums of around $\$ 10,000$ to groups of 20 or so young people who club together to apply.

They set up enterprises and work longer hours in their new trades. Average earnings rose by almost $50 \%$ in four years. The paper reports that in Ghana, where the biggest Households were women, the program gave small sums $(\$ 120)$ to a random selection of business owners, some unconditionally, some requiring the owner to buy something for his or her firm. The conditional benefits proved more useful: Profits at firms that got such payments were twice as high after three years as at firms that got cash with no strings attached (The Economist 2013)

In a study by Ladzani and Netswera (2009) on support for rural small businesses in Limpopo Province, South Africa, in which they examine the type of support systems and Programs required and available for the growth and development of rural SMMEs in Limpopo, one of the key findings of the study indicates that nearly $80 \%$ of entrepreneurs perceived finance to be inaccessible and thus the most common constraint for their growth.

According to the USDA (United States Department of Agriculture), it offers financial assistance for rural health care facilities and essential equipment, including first-responder equipment, through the Community Facilities program authorized by the Consolidated Farm and Rural Development Act. Community Facilities offers financing in the form of loans, both direct and guaranteed, and grants to eligible participants in rural areas. In fiscal year 2005, the USDA Community Facilities program funded $\$ 207$ million in rural health care projects serving nearly 2.1 million people in rural areas. Individuals living in rural areas are more likely to be uninsured than those in urban areas ( 24 per cent versus 18 per cent), although they are 50 per cent more likely to have Medicaid coverage.

Two-thirds of the uninsured are low-income families, and 30 per cent are children. They further report that even those lower-income individuals who are working often lack health insurance due to the structure of employment in rural areas specifically, smaller employers, lower wages, and greater prevalence of self-employment.

\subsection{Identification of recipients for direct support}

In a study by Deininger and Okidi (2001) on "Rural Households: Incomes, Productivity and NonFarm Enterprises", they emphasize the critical need to focus on income growth of the rural poor for overall poverty reduction in Uganda by way of descriptive evidence and econometric analysis. Households with low-income levels in 1992, but 
with human and physical capital assets, were able to benefit the most from overall growth. Rural farmers diversified into non-farm income generation and established non-agricultural enterprises of which education and access to financial markets played a crucial role.

Deininger and Okidi (2001) use information from 1992/1993 and 1993/1994 national surveys to explore the production, input demand, and establishment of non-farm enterprises, and they argue that enabling the rural poor to accumulate additional human and physical capital, increasing the returns to assets they already own through technical progress, increased diversification, market integration, commercialization, and growth of rural non-farm enterprises are key elements of any strategy aimed at equitable growth and broad-based poverty reduction. The study further suggests a regional balance in policies aimed at promoting education, infrastructure, and agricultural productivity to ensure broad access to economic opportunities (Deininger and Okidi, 2001).

The failure of which as in the past will not only cut the tight link between growth and poverty reduction but also threaten the sustainability of economic growth in a more fundamental way. MINALOC (2009), maintains that providing a level of support for the household that is sufficient will be is determined by the size of the household taking into account any other support the household may receive. The basis for the identification of potential recipients is the Ubudehe process and social map at Umudugudu level, which includes all the extremely poor in the village.

The committees will be asked to identify which households are in the bottom two categories (MINALOC, 2009). Within these two categories, those that are landless (or have less than 0.25 hectares) and have no adult (at least 18 years old) capable of manual labour as required for public works will be assigned to the Direct Support Program eligibility list (MINALOC, 2009).

Direct support is seen as a benefit of last resort for landless households who cannot benefit from a public works program or the provision of credit facilities without considerable training and guidance. Also, the committee will note against any household on the list any known support from other programs or any other source. This will be further discussed at the Joint Action Development Forum of the Umurenge, which brings some different stakeholders and implementers together. In this way, the Ubudehe committee produces a list of potential direct support recipients (and a similar list for potential public works participants and the list is used as the mechanism to identify and to rank households who will receive direct support.

\subsection{The payment process}

In a study by Mutezo, (2005) on obstacles in the access to SMME finance, the thesis assessed the economic contribution of SMMEs in South Africa and the key constraints, in particular, obstacles to accessing finance. The study notes in its findings that conventional financing mechanisms do not allow for the cost-effective provision of finance to large numbers of entrepreneurs seeking small quantities of finances.

Moreover, MINALOC (2009) highlights that Payments of direct support must be made regularly in a manner that is convenient to the recipient household. Payments mechanisms should be secure, not subject to possible manipulation, and free to the beneficiary. Direct support will build on the payment process in place for public works, but payments will be made monthly at the beginning of the month. Payments is meant to make directly into Bank Accounts of clients. Plans are in place for the provision of banking services at least on a part-time basis at locations convenient to most villages.

The manual further maintains that direct support recipients will be given the option of having a small part of their monthly allowance retained as personal savings. To encourage saving, consideration will be given to enhance the amount saved by an additional grant of direct support, if (a) savings are made regularly and (b) savings are held for a minimum period.

\subsection{Duration of direct support}

Brasil (2013) in a presentation on turning the Invisible into Visible for Decisions at the 11th Annual Worldwide TOCICO Conference maintains that timing in projects is as important as "time" is. For one single project to be a success, many dimensions need to be in harmony. There are dimensions where things or references move continuously. There are dimensions where things or references move discretely. Sometimes, dimensions are mixed and the decision process is seen as easier. After decisions are made and implemented, nature shows the effects. Understanding the different dimensions is essential to harmonizing perceptions, decisions, language, solutions, measurements, phases and criteria. Harmonizing and the right timing need to be inherently simple but are not necessarily easy.

According to MINALOC (2009), direct support is intended as a short term provision of cash support to allow a household to develop skills to help them become self-sufficient. However, it is recognised that some households will not have the capacity to become self-sufficient and will require direct support for longer periods. Direct support will be awarded for 6 months and then reviewed, during which time households will access training and sensitisation, and possibly small amounts of credit (if they qualify and it is available). At the time of the 6 monthly reviews: 
Households that will have graduated are removed from the list, households not able to graduate but able to move to public works will be removed from the list and also households which cannot graduate or move to public works will remain on the list for the next period, and may remain on the list indefinitely (they may require long term assistance. Finally, those which can take advantage of training and sensitization but who have not made any effort to do so may be removed from the list.

Any new household meeting the Program criteria will be added to the list. Entitlement to direct support will cease at the six month review period if a household has graduated or one adult member of the household becomes able to take up public works.

\subsection{Training and credit access}

In a study by Mensah and Benedict (2009) on "Entrepreneurship training and poverty alleviation, they attempt to determine the major long-term role that hands-on entrepreneurship training could play in poverty alleviation and job creation in one of the poorest regions of South Africa - the eastern Free State. The findings indicate that while hand-out measures by the government to alleviate poverty, with their unintended consequences of violent protests and demonstrations, may only help some of the poor in the short term, training in entrepreneurship and the provision of other facilities could give poor owners of micro and small enterprises opportunities to grow their businesses and lift themselves and others out of poverty (Mensah and Benedict, 2009).

Lack of management skills training is highlighted by Abor and Quartey (2010) in an investigation of Issues in Small and Medium Enterprise Development in Ghana and South Africa", this paper discusses the characteristics and contributions of SMEs to economic development, as well as the constraints to SME development in developing countries with particular reference to Ghana and South Africa. It reports that despite the recognition of the important roles that SMEs play in these countries, their development is largely constrained by many factors, which include among others a lack of access to appropriate technology; limited access to international markets; the existence of laws, regulations and rules that impede the development of the sector; weak institutional capacity; a lack of management skills and training and, most importantly, finance.

The Direct Support Operation Manual (2009) maintains that the direct support income transfer will be combined with a core package of sensitisation, training and savings. According to the operational framework, it is the intention that all recipients will receive an initial level of sensitisation during which they will be educated on the goals of the VUP program, the importance of saving, and the possibilities of developing skills. Some direct support recipients will be offered more specific training to assist them to become self-sufficient.

The aim is to address the barriers that prevent the poor from accessing credit and other services, and the barriers to entering the market economy. The direct support package concept, the amount and duration of assistance, the expectations of graduation, and household obligations, will be explained to all direct support clients. Recipients will also be advised of the importance of savings and the range of existing opportunities and potentials which they could access the culture of savings and using money in general.

The function of preparatory microfinance is to provide a pathway towards microfinance for lowincome and vulnerable individuals who because of their extreme poverty are not in a position to be entrepreneurial or able to benefit from microfinance loans. The approach consists of a 'staircase', leading from extreme deprivation and risk aversion to purposive involvement in the cash economy, of which ability to take advantage of microfinance loans is a component.

\subsection{Vision 2020 Umurenge Program (VUP) in Rwanda}

The Vision 2020 Umurenge Program (VUP) uses the existing decentralization system and leverages technical and financial assistance to accelerate the rate of poverty reduction in Rwanda. The aim is to eradicate extreme poverty by 2020 . The initiative builds on past experiences which show that "isolated" interventions by sector ministries, donors or NGOs are not sufficient to lift people out of extreme poverty cost-effectively and sustainably.

The other extreme recourse to "integrated" development has also shown its limits in many circumstances. One of the main limitations of both isolated and integrated approaches has been the failure to address two of the most important insights of economics: (i) "resources are scarce" and (ii) "people respond to incentives." Because resources are scarce compared to people's needs, choices must be made.

When choices are made for people (e.g. centralized planning), there are risks of not satisfying these needs or distorting local incentives; this generally leads to wastes of resources. When choices are made by people (e.g. participatory mechanisms), these risks are alleviated but the incentives may not be compatible with the stated aim of eradicating extreme poverty. To capture these insights, the VUP balances central guidelines for socio-economic transformation (i.e. economic growth, job creation and extreme poverty eradication) with local participatory mechanisms.

This intends to make the best possible use of scarce resources while, at the same time, ensuring 
adequate local incentives for sustainable progress. The VUP is organized around three components. The first component revives public works but planned using community-based participatory approaches (e.g. Ubudehe) to build community assets and create off-farm employment infrastructure.

Examples include projects like watershed management, terracing, water harvesting, irrigation, feeder/access roads construction, the building of classrooms, health facilities, training centres, business workshops, village settlements, etc. The second component innovates with credit packages to tackle extreme poverty as well as to foster entrepreneurship and off-farm employment opportunities; these packages are designed to make the best possible use of scarce public resources, involve the private financial sector, and provide people with incentives to improve their productive capacities.

Examples include credits to diversify/specialize farming/livestock activities, develop off-farm skills, purchase/build household/business assets, etc. The third component includes direct supports to improve access to social services or to provide for landless i. households with no members qualifying for public works or credit packages; such unconditional supports seek to expand health and education coverage as well as to encourage the development of "appropriate" skills, handicraft, or social service activities. Targeting people's productive capacities will have at least three additional benefits. First, it will allow creating off-farm employment opportunities, thereby facilitating the eventual transition to a modern knowledge-based society according to Rwanda Vision 2020.

Second, it will allow accelerating the process of monetization and formalization of the economy, thereby ensuring long-term sustainability. Third, it will allow redirecting social protection to the neediest people who are landless and unable to work, thereby rationalizing and improving the effectiveness of social protection programs, along with the social iil. protection strategy. The VUP features as a flagship program under the Economic Development and Poverty Reduction Strategy covering the budget years 2008 to 2012. As such, the VUP seek to instigate changes in the efficiency of poverty reduction.

This will require managing change in three related areas. First, assist local governments to coordinate the implementation of national sector ministriese $^{\text {ee }}$ strategies. Second, install the notion of interconnectedness of services across sector ministries. Third, change attitudes through pro-active interventions of all sector ministries to accelerate the rate of poverty reduction in Rwanda. Consistent with the assessment for achieving the Millennium Development Goals and the objectives of Rwanda Vision 2020, the VUP requires investments of $\$ 72$ per capita and per year. Starting with 30 Imirenge (out of 416 in the country), it initially targets a population of about 600,000 people $(=30 / 416 \times 9$ million population). Thus, the VUP requires $\$ 44$ million or RwF 24 billion for the first year. It is expected that $50 \%$ will be required for public works (i.e. salaries and material), $30 \%$ for credit packages, and $20 \%$ for direct supports (GoR, 2007).

The appeal of such program components is that $90 \%$ of the money goes directly in the pockets of the poor. Also, the money going to credit packages is revolving; indeed, it is expected that at least $80 \%$ of that money can be re-used for further loans by microfinance institutions. Success will be defined specifically to both key achievements in the start-up pilot phase and the capacity of local governments to carry out the program components in a decentralized fashion. A conditional and gradual scaling up to other Imirenge within 3-5 years could be possible.

The VUP is organized around three components to implement the client-based solutions and put money straight into the pockets of hard-working Rwandans who participate in the VUP:

Public works are envisioned using community-based participatory approaches (e.g. Ubudehe) and intend to build productive community assets. Since private land ownership is widespread in Rwanda, public works can take place on either public or private land (e.g. terracing). However, the case must be made that the assets benefit the community at large. Indeed, when such benefits are clear, the community will have the incentive, or vested interest, to conduct the maintenance of these community assets, thereby ensuring sustainability.

ii. Credit packages to tackle extreme poverty as well as to foster entrepreneurship and off-farm employment opportunities; these packages are designed to make the best possible use of scarce public resources, involve the private financial sector, and provide people with incentives to improve their productive capacities.

ii. Direct supports to improve access social services or to provide for landless households with no members qualifying for public works or credit packages; such unconditional supports seek to expand health and education coverage as well as to encourage the development of "appropriate" skills, handicraft, or social service activities.

\subsection{Empirical Literature}

According to the study conducted by Austin, Chow, Hastings, Taylor, Johnson, Lemon and Leer, (2004), it revealed that low-income families face significant barriers to using public and private services and to increasing earnings from work. Many low-income families who would otherwise be eligible for government cash or in-kind assistance either do not know they are eligible or find that the application process is an obstacle to receiving 
assistance (Zedlewski, Nelson, Edin, Koball, Pomper and Roberts, 2003).

In a study by Ayako (2006) on lessons of the experience with direct support to schools mechanism, he shows that the Direct Support to Schools mechanism, designed to facilitate the provision of Universal Primary Education (UPE), had been generally well-received and had achieved positive outcomes such as improved access to primary education with enrolment rates increasing rapidly. The study identified key elements of successful implementation of the Direct Support to School (DSS) mechanism including (i) involvement of multiple stakeholders, business, cultural institutions, students and marginalized groups. Besides, it concluded that effective literacy programs may have to accompany capacity building for local communities. This was relevant because lack of technical skills by community leaders has led to incomplete participation; (ii) clarification of roles of all stakeholders also seems to be important for the success of the program.

Finally, the study identified many obstacles in the implementation of the Direct Support to School (DSS)mechanism such as i) political interference; ii) weak organization and control; iii) mismanagement (embezzlement) of funds; iv) weak involvement of the community in decision-making; v) weak supervision and monitoring by the MOE; vi) general lack of management skills by many principals and their staff, especially in expenditure and revenue control, budget formulation; viii) duplication in the use of funds; ix) delays in the acquisition of inputs; $\mathrm{x})$ shortage and poor quality of education infrastructure including classrooms; xi) shortage of trained teachers. This following part of the study will focus on the following critical factors selected from the Direct Support Operational Manual as core components of the direct support project (MINALOC, 2009).

Mujawase (2017) did a study on the importance of the Vision 2020 Umurenge Program as a government tool to eradicate poverty in Rwanda. This study was done to assess the "Importance of VUP as a government tool to eradicate extreme poverty in Rwanda" case of the study being Mageragere Sector of Nyarugenge District, Kigali City. The respondents were Households of VUP in Mageragere Sector. The result of the study highly recommended that, based on the contribution of VUP to the poorest families in Rwanda, the government (decision-makers) should help the Households by increasing the duration of the program from six months to at least one year, per group in a given sector to make some reasonable savings that will make them self-sustaining even after graduation from the program.

Birungi (2017), in her study on the contribution of the CDF (Common Development Fund) to poverty reduction in Rwanda through the VUP in Rulindo District found that after noting that an utmost number of Rwandan population lives in a state of poverty and generally resides in rural areas where it lives mainly on agriculture, we chose this research topic entitled "Study on the Contribution of the common development Fund (CDF) to poverty reduction in Rwanda through the VUP in Rulindo District. The period of this study is 2008 to 2009 .

The results of the study are to encourage the Households of VUP for increasing income and increase the effort to reduce the poverty. In conclusion, both researchers had the specific objectives to assess the level of income increase for the poor families, to evaluate standards of living of the Households of the program in the sector understudy, to examine the level of poverty decrease in the sector understudy, to analyze the level of employment offered or facilitated by VUP and to make suggestions to policymakers, management unit and implementing entities.

Mpayimana (2016) carried out a study to investigate the effects stakeholders' involvement on the rural project performance in Rwanda through analysing VUP public works projects implemented in sectors of Huye District. The specific objectives included showing the extent to which VUP PW project Households were involved in rural projects; showing the level VUP PW project performance was appreciated and investigating the effects of stakeholders' involvement on project performance. Mixed methods research strategies were employed, both quantitative and qualitative data were gathered for this research.

The quantitative data was collected through closed-ended questionnaires, while the qualitative data was collected through structured interviews with project staff and focus group discussion with project Households. It was found that stakeholders' involvement especially project Households in project positively affected the project performance as VUP PW project objectives. The study recommended that involvement of stakeholders by themselves and by project managers is helpful to the project performance by helping it to reach its objectives if it results in the ownership, increased commitment and support to it. And this depends on continuing attentions. Because the intent of the project is participatory, it is recommended that VUP PW project stakeholders especially its Households should early be involved in any assessment and pre-planning activities as well as planning, implementation, monitoring and evaluation.

Mpambara and Umutoni (2015) carried out a study on the contribution of VUP Credit Packages to poverty alleviation in Rulindo District. The respondents were Households of VUP in Rusiga Sector. The authors assessed the contribution of VUP Credit Packages to poverty alleviation in Rusiga 
Sector. Basing on the findings, it was revealed that, there was a change in income by almost $100 \%$, poverty alleviation as respondents get a monthly income and above three-quarters of them get more than 20,000 Rwf (above US dollar per day), saving behaviour was introduced where $100 \%$ of Households save every month, either in Umurenge SACCO, buying goats or joining financial groups (Ibimina), improvement of welfare is changing rapidly and there is a gradual change in job creation and another bank (Mpambara and Umutoni, 2015).

Mpayimana (2016) did a study on the contribution of VUP activities on poverty reduction to mend deprived peoples living conditions, investigate how VUP pillars; public works, direct support, and financial services) have contributed in the process of poverty reduction to see whether the government has room to manoeuvre, to create its development agenda. Data analysis methods used were descriptive statistics as a preliminary investigation procedure to gain an understanding of inherent significant socio-economic characteristics of the VUP Households and the leaders of the Program in Nyarubaka Sector.

The analysis was revealed the difference for the budget that is statistically significant for P-value of 0.00572 , and for direct support, P-value is 0.00217 , financial services it $\mathrm{P}$-value is 0.0032 and public works end up with P-value of 0.0542 . The overall VUP components have shown a significant probability between allocation and execution from 2009-2011. He observed that VUP as a government approach has changed the trends of governance. For instance, it encourages moving from a top-down, autocratic approach associated with the past to developing local self-government structures which can facilitate collective action. With economic growth, the government would be able to invest in road infrastructure, which would create more employment opportunities and thus reduce poverty.

According to the direct support, Operational Framework and Procedure Manual (2009) direct support are intended as a short term provision of cash support to allow a household to develop skills to help them become self-sufficient. However, it is affirmed that some households will not have the capacity to become self-sufficient and will require direct support for longer periods. No empirical data is showing the relationship between the direct support and economic development of Households and therefore this study seeks to address this issue.

The study conducted by Mutezo, (2005) sought to assess the economic contribution of SMMEs in South Africa and the key constraints, in particular, obstacles to accessing finance; and he stated that conventional financing mechanisms do not allow for the cost-effective provision of finance to large numbers of Households seeking small quantities of finances. However, his study was talking about entrepreneurs who may not be necessary for being poor.

This study is conducted to assess the role of such funding to low-income earners. The study conducted by Austin, et al (2004) argues that many low-income families eligible for government cash or in-kind assistance either do not know they are eligible or find that the application process is an obstacle to receiving assistance. In this study, the identification process starts from the grassroots whereby the community members and the local leaders are involved in identifying the Households. Therefore the situation of identification is sometimes different depending on the structure in place. This study narrows to the effect of such support on Households living standards.

The literature indicates that none of the previous researchers particularly in Rwanda has attempted to conducts research to assess the relationship between direct support project and socio-economic development of Households. So, it is in this way that I come up to carry out research in Ruhango District to see whether the direct support had a meaning in terms of socio-economic development of the population Households in Mwendo sector / Ruhango district as the researcher's case study.

\section{Materials and Methods}

The research design for this study is quantitative, and quantitative. Burns and Grove (2005), states that sampling involves selecting a group of people, events or behaviours or other elements with which you conduct the study. The study covers a target population of 22,582 covered the households who are direct Households of VUP. VUP targets only the unemployed in the different sectors of Mwendo Sector of Ruhango District.

According to Grinnell and Williams (1990), the sample size is the number of people or objects in the sample. The proposed sample size was determined using the two successive formulas posited by Glenn (1992).

Formula 1: By substitution of the value of

$$
\begin{aligned}
& n_{o}=246 \\
& n=\frac{246}{1+\frac{(246-1)}{22,582}} \quad=\frac{246}{1+0.01}=\frac{246}{1.01}=244
\end{aligned}
$$

The sample size of the study was covered by 244 respondents in all Mwendo sector of Muhanga District to represent the whole Households of direct support project of the VUP Umurenge program. 
The study used a combination of purposive and convenience sampling techniques. Purposive sampling technique is a non-probability method, which is used to select a sample whose characteristics match study objectives. In this study, purposive sampling was used to select project beneficiaries. Convenience sampling is a nonprobability sampling method characterized by selecting study participants based on their convenience or accessibility to the researcher. In this study, the researcher sampled the participants who benefited from VUP.

Several data collection methods have used including focus groups discussions, questionnaire, and reports were used as tools for collecting qualitative and quantitative data. A discussion was mainly based on the "soft system checklist" or a number of questions used by VUP process to test the level of participation and involvement of the population in this VUP 2020. This technique was combined with a random check in some sectors to be sure about what and how activities are done. Like other qualitative methods, focus group give insights into not just what participants think, but also why they think it, questionnaires: as a research tool forms a basis to furnish reasonably more reliable information in quite a short time. In Rwanda, there is an advantage of speaking one language "Kinyarwanda". This will be an important opportunity to collect data easily. The questionnaires translated into "Kinyarwanda".

The primary data collected through, focus group discussions and participatory discussions in the sector council meeting which regroup all population. The secondary data was obtained mainly on the government policy documents on poverty reduction which leads to Rwanda economic and social development and reports. The four documents are Rwanda vision 2020, the Poverty Reduction Strategy Paper and the National Investment Strategy, Social Protection Policy, Strategy and Implementation Plan, Project document and VUP annual report 2015/2018, the VUP project is one of the projects to implement those policies at the grassroots level, which was tried to aggregate some of those data estimated to contribute to this research.

Reliability is defined as the extent or the degree to which research instruments produce similar findings when presented to different but similar study contexts. Reliability refers to the consistency, accuracy, or dependability of the instrument (Nahid, 2003). The data collected from respondents were obtained by the way of an approval procedure of the body of Ruhango District and Mwendo Sector. Piloting of the research tool was used to test the reliability of the research. The pilot test was conducted among 24 respondents which are about $10 \%$ of the proposed sample population (Nahid, 2003). Cronbach's alpha was used in the calculation of the internal reliability index, and values $(\alpha) 0.9 \leq$ $\alpha \leq 0.7$ exhibited the acceptable levels of internal consistency.

The researcher makes sure that the given information was a valid source of reference; therefore, this contributed to the assurance that the information was validated and valued. The questionnaires were distributed to the concerned respondents who were selected from the whole population. The data collected measured to ensure its magnitude by using frequency and percentages, to prove the instrument reliability with the study objectives.

The validity of a research instrument refers to the extent to which an instrument measures what it is supposed to measure (Nahid 2003). The researcher used content validity techniques to verify and ensure that the questions which asked were designed to examine the contribution of VUP through Direct Support Project to the social-economic development of the Households.

To carry out data analysis of the collected data some methods used. Those methods to process the data included: editing, coding, and tabulating. The researcher use also SPSS computer program to interpret data. Data were analysed based on the research objectives and questions. After the data processing, tables, and percentages used to interpret the data to establish the impact of direct support project on the Households.

The ethical consideration for direct support project through VUP is seen to be having an impact on poor people's lives and socio-economic development and districts are keen for it to be scaledup into more sectors more quickly. However, the budget required for VUP to be able to operate at a national scale is significant.

Several activities are planned and being carried out to support mobilization of resources for VUP and their most effective use for maximum impact. They include: Conducting an impact study in 2016, this provided strong evidence on household and community poverty changes as a result of VUP, what is working well and areas that can be strengthened for even greater impact on Integration of VUP activities into District Development Plans and Imihigo. This helped to ensure timely and highquality delivery of the VUP Development of scalingup and financing strategies. The scaling-up strategy included special attention to the poorest sectors, greater harmonization and coordination of the VUP with other Programs in the social protection sector, Validation of the Ubudehe database, This was the basis for household targeting by several government Programs, including VUP.

\section{Results and Discussion}

This section presents data collected from the field and interprets them according to the objectives 
of the study. These data were obtained from the questionnaires and interview with the selected respondents.

Demographic characteristics of respondents were identified. The purpose of showing the identity of respondents is to clarify their status which showed that the results are done on a different group of age; marital status, gender, experience and academic background.

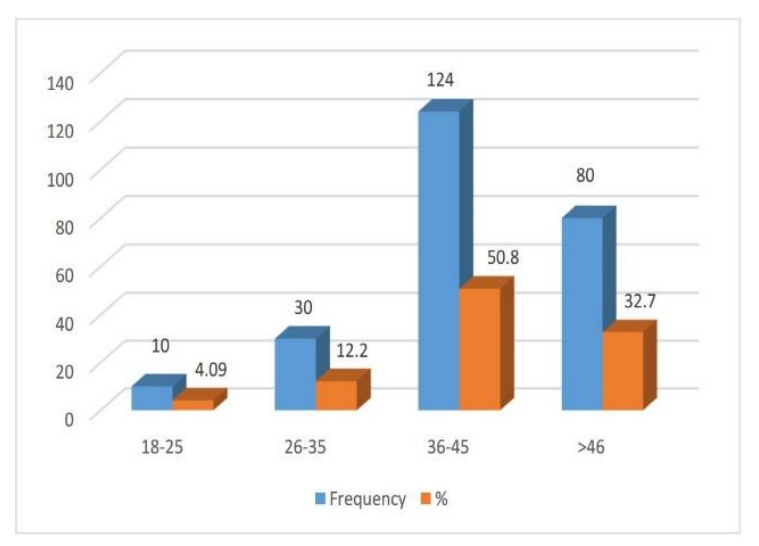

Figure 1: Group of ages of respondents

The results in figure 1 show that the majority of the respondents were between the age of 36-45 and a small percentage of $4.09 \%$ which means that this group of age is not concerned in this program, 32.7\% were above 46 years which means that direct support program targets elderly people who may not be able to support themselves economically and finally $12.2 \%$ were between $26-35$ years who are the one participated in VUP activities generating income to facilitate them to sustain their livelihood.

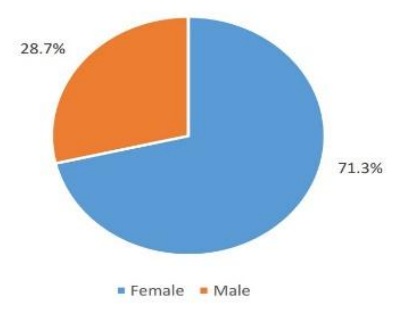

Figure 1: Identification of respondents

The results about the gender in figure 2 shows the sampled respondents from both households and the leaders of the program. It is indicated that the majority of the respondents $71.3 \%$ were female and $28.7 \%$ of the total respondents were male. In general, the female seemed to form a large number in this sphere of influence because in most cases women in the society especially in African contexts are unprivileged. They are disadvantaged by the culture believes that the woman roles mainly revolve in household chores and therefore the majority of them do not have chance to get out of this perpetual circle rendering them prone victims of poverty circle.

Consequently, due to recent rigorous campaigns of championing of women empowerment, many women have come forth to be in the front line and therefore we find that in such issues which mainly touch women, majority of those who have capacity takes up this task. This is why we find that women form the majority of both categories in this study.

Table 4.2: Education Background

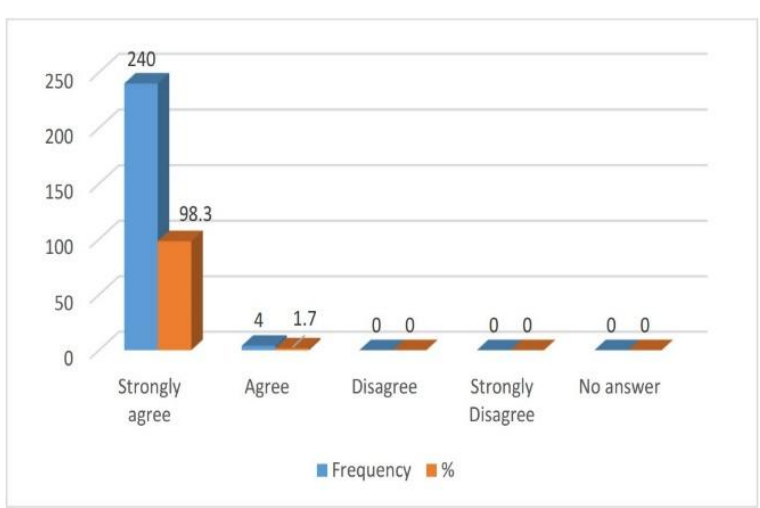

Figure 3: Education Background

In figure.3, the research wants to assess the level of education of the respondents to distinguish the respondents' potential skills and also to assess the intellectual trends of the households of the direct support program. It was found out that $58.1 \%$ of the households were not educated, $34.9 \%$ were primary school dropouts and $6.1 \%$ had professional training and $0.9 \%$ was secondary school dropouts while no one has a university education. This implies that a direct support program is meant to assist people with a low level of education.

\subsection{Results}

The researcher wanted to find out the process of identifying and selecting direct support households to find out whether it serves the purpose of assisting the low-income earners in Rwanda. Various questions were asked to both the households and leaders relating to this project matter. The following tables provide the statistics of the information sought. 


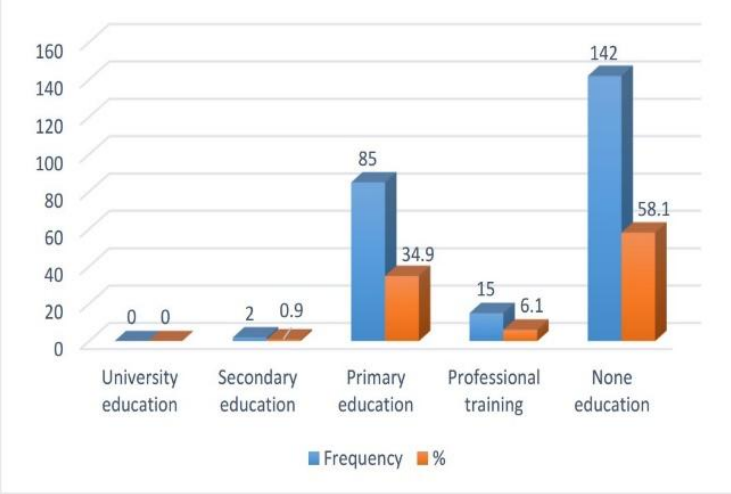

Figure 4: Use of Ubudehe for identifying and selecting households

The study established $98.3 \%$ of the respondents agreed strongly that Ubudehe process is both used in the identification of target households of direct support in the district. However, most of the households of direct support households have failed to from graduate and achieving self-sustainability through the stage of Ubudehe because they have gotten used of a handout and forget about working for themselves to earn living.

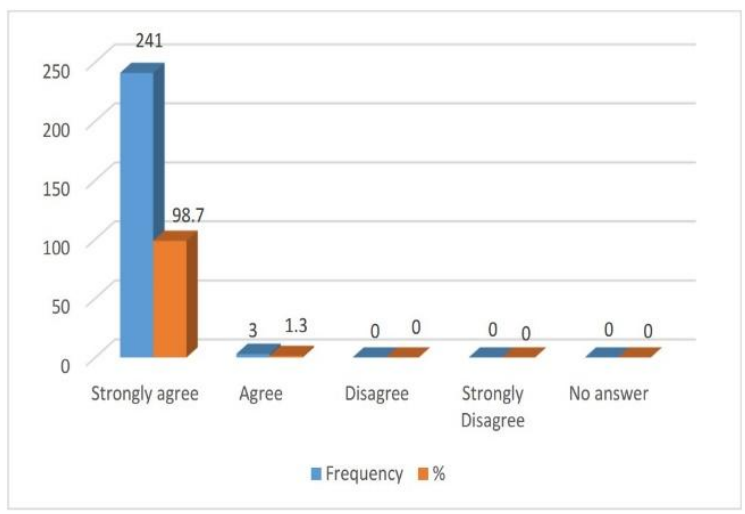

Figure 5: Minimum age qualification for direct support households

Figure 5 shows the level of agreement of the respondents according to the selection of households according to their minimum age and capacity, they were also asked the criteria which the households of the program are being selected and the results indicated that $98.7 \%$ of them highlighted that they strongly concur that all direct support households are adults above 18 years incapable of manual labour and $1.7 \%$ agreed also with the statement while no one has refused. Initially, in the table showing the age bracket of the respondents, the study established that majority of the households are elderly people with a low level of education and are subjected to the perpetual circle of poverty as indicated in the rating of Ubudehe. This means that no child or youth who is considered to have the ability to get an education and work for a living is eligible to access direct support program.

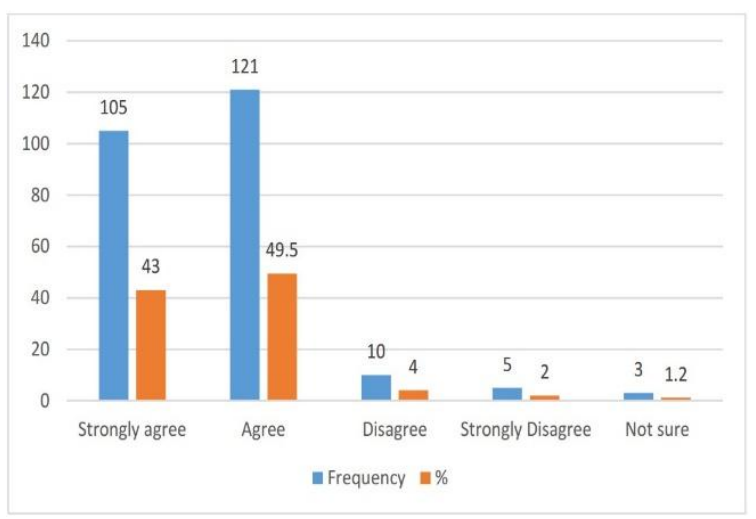

Figure 6: Economic development among direct support households

Figure 6 shows whether the direct support received from VUP has impacted them to move from poverty to self-reliance. The majority of respondents $49.5 \%$ agreed with the statement, $43 \%$ were strongly agreed that they have economically developed, $4 \%$ disagreed with the statement, and $2 \%$ strongly disagreed while $1.2 \%$ they were not sure about the statement. This indicates a highly significant level of agreement of their economic development level through the direct support program to better lives of the households. Coupled with the fact that the majority of respondents agreed that they do graduate to higher levels of Ubudehe where they may be considered self-reliant.

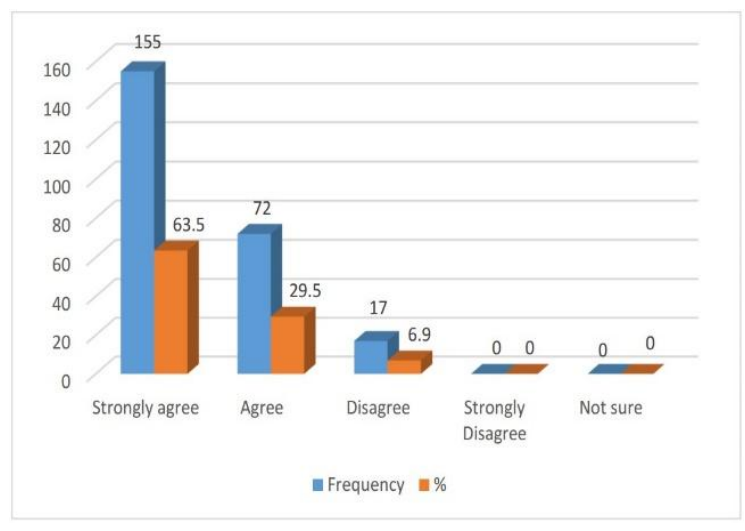

Figure 7: Respondents views on the selection of households on the direct support

Figure 7 shows the respondents view whether there are transparency and reliability way in selecting the right targets for direct support intervention, where the majority $63.5 \%$ were agreed strongly that the selection of households was perfect in transparency, 29.5\% were agreed and 6.9 disagreed 
with the statement. This means that the target of direct support to the low-income earners was achieved perfectly.

The researcher wanted to find out the socioeconomic activities undertaken by the members who benefit from direct support program in Rwanda to evaluate whether they are indeed progressing their lives. And also the researcher wanted to know if this support assisted them to achieve their goals of moving from their vicious circle of poverty.

Table 1: Economic activities are undertaken by the households

\begin{tabular}{ccc}
\hline $\begin{array}{c}\text { Activities are } \\
\text { undertaken }\end{array}$ & Frequency & $\%$ \\
\hline $\begin{array}{c}\text { Subsistence (Buying } \\
\text { food + supplies) } \\
\text { Medication (Paying for } \\
\text { medical insurance) }\end{array}$ & 244 & 100 \\
Fruits and vegetable & 145 & 59.4 \\
$\quad$ Grocery) & 37 & 15.1 \\
Asset buying & 231 & 94.6 \\
Cooperative (saving) & 108 & 44.2 \\
Loan re-servicing & 0 & 0 \\
Animal rearing (goats, \\
pigs)
\end{tabular}

The results from respondents here show that out 244 households respondents of this research all of them $(100 \%)$ stated that direct support program has enabled them to undertake some economic activities specifically the subsistence business like buying food and supplies, $94.6 \%$ of the total respondents stated that direct support program has enabled them to buy assets, $59.4 \%$ mentioned that they can buy medication, for instance, paying for medical insurance and drugs. However, the government provides them with mituelle de santé. Additionally, $45.4 \%$ of the respondents said that they have been able to pay school fees although the leaders said that the government also provides the dependent of this group with school fees. What they do is to facilitate their school gong children with just a few things necessary for learning.

The study also established that $37.2 \%$ of the respondents have been able to improve their lives by acquiring assets by buying animals like goats, chicken and pigs using the direct support program funds. This is a subsistence farming which requires little capital but it facilitates the households to create a source of income. Some of them also have a small piece of land where they cultivate to get food so that they avoid buying them to the market, $44.2 \%$ respondents said that they have joined cooperatives where they contributed money for saving for their future and other $4 \%$ of the total respondents highlighted that they have been used it to conduct other economic activities like selling water, fruits, vegetables and many more.

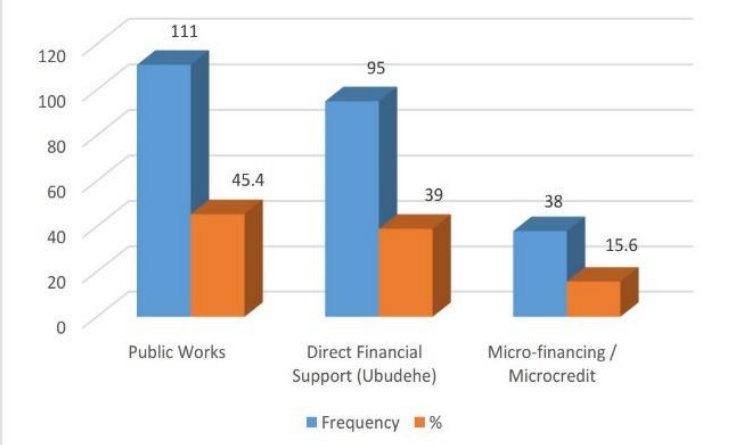

Figure 8: VUP project main activities in Ruhango District

VUP activities in Ruhango District were composed of three types of activities, figure 9 shows that $45.4 \%$ of the total respondents said that they were in public works where they funds after working in different public activities in the village, 39\% were in direct financial support project (ubudehe) where they get direct fund from Umurenge SACCO account to help them to survive and $15.6 \%$ were in microfinancing / microcredit where they get support like small loans from the SACCO to invest in small business which will help them to get some money to use in their daily activities in their families. It means that through the Government policy, the Government of Rwanda has contributed to the social-economic activities which will improve their life.

The study wanted to find out the effect of payment and delivery process of funds households' economic productivity. This was important because, in some incidences, households complain that the payment might delay hence affecting their efficiency. When the money is delayed, it may affect the operations and the moral to execute some project of households.

Table 2: Respondents views on the households receive funds monthly

\begin{tabular}{|c|c|c|c|}
\hline \multicolumn{2}{|c|}{$\begin{array}{l}\text { Period of receiving } \\
\text { direct support }\end{array}$} & \multirow{2}{*}{$\frac{\text { Frequency }}{25}$} & \multirow{2}{*}{$\frac{\%}{10.2}$} \\
\hline Valid & Strongly agree & & \\
\hline & Agree & 201 & 82.3 \\
\hline & Disagree & 13 & 5.3 \\
\hline & $\begin{array}{l}\text { Strongly } \\
\text { Disagree }\end{array}$ & 0 & 0 \\
\hline & Not sure & 5 & 2 \\
\hline & Total & 244 & 100 \\
\hline
\end{tabular}


Table 2 shows that $82.3 \%$ of the respondents agreed normally, $10.2 \%$ agreed strongly that they have got direct support on regular basis, 5.3\% disagreed with the statement, and $2 \%$ were not sure about the statement while no one was strongly disagreed with the statement. It implies that on average, more than $92.5 \%$ agreed that indeed the households receive support monthly to assist their livelihood.

Table 3: Respondents views on the process and duration for the reception of support

\begin{tabular}{|c|c|c|}
\hline $\begin{array}{l}\text { Process and duration for } \\
\text { receipts }\end{array}$ & Frequency & $\%$ \\
\hline Valid Strongly agree & 55 & 22.5 \\
\hline Agree & 145 & 59.4 \\
\hline Disagree & 11 & 4.5 \\
\hline Strongly Disagree & 0 & 0 \\
\hline Not sure & 33 & 13.5 \\
\hline Total & 244 & 100 \\
\hline
\end{tabular}

The researchers also wanted to find out from the households is the process and duration for the reception of direct support funds is predictable and reliable. Table 3 shows that $59.4 \%$ of the respondents stated that it is predictable and reliable, $22.5 \%$ were strongly agreed, and $13.5 \%$ were not sure about the statement, $4.5 \%$ disagreed with the statement. It means that those statistics allowed the researcher to say that it is true that in most cases since this direct support program is given out every month then it is considered to be reliable.

Table 4: Respondents views about the payment methods

\begin{tabular}{cll}
\hline Payments methods & Frequency & $\%$ \\
\hline Valid Strongly agree & 199 & 81.5 \\
Agree & 45 & 18.5 \\
Disagree & 0 & 0 \\
Strongly & 0 & 0 \\
Disagree & & 0 \\
Not sure & 0 & 100 \\
Total & 244 &
\end{tabular}

The table above shows the method of receiving the money of the households, where the results show that $81.5 \%$ were strongly agreed and $19.5 \%$ were agreed on which means that the whole respondents assumed that they get funds via bank account and never receive cash by hands. This implies that they must have a bank account once they are registered in this program.
Table 5: Respondents views about grants as an incentive to encourage savings

\begin{tabular}{cll}
\hline Additional grants & Frequency & $\%$ \\
\hline Valid Strongly agree & 231 & 94.6 \\
Agree & 13 & 5.4 \\
Disagree & 0 & 0 \\
$\begin{array}{l}\text { Strongly } \\
\text { Disagree }\end{array}$ & 0 & 0 \\
Not sure & 0 & 0 \\
Total & 244 & 100 \\
\hline
\end{tabular}

The researchers wanted to find out the methods used to encourage the households to practice saving and the information obtained indicated in table 5 shows that $94.6 \%$ of the respondents were strongly agreed and $5.4 \%$ agreed mildly they are incentives such as additional grants given as a way to encourage maximum saving by direct support households in the sector. Saving money is an important alternative to consumer credit to help people meet periodic needs. But many people on low incomes do not have money saved formally in a regulated saving account.

Table 6: Respondents views on the six months receiving phase mechanism

\begin{tabular}{|c|c|c|}
\hline \multicolumn{3}{|c|}{$\begin{array}{l}\text { Households } \\
\text { hardworking } \quad \text { to }\end{array}$} \\
\hline \multirow{2}{*}{$\begin{array}{l}\text { Vali } \text { Strongly agree } \\
\text { d } \quad \text { Agree }\end{array}$} & 5 & 2 \\
\hline & 8 & 3.2 \\
\hline Disagree & 81 & 33.1 \\
\hline $\begin{array}{l}\text { Strongly } \\
\text { Disagree }\end{array}$ & 100 & 40.9 \\
\hline Not sure & 50 & 20.4 \\
\hline Total & 244 & 100 \\
\hline
\end{tabular}

The study also wanted to find out the appreciate mechanism used to evaluate the households to enable them to graduate to different levels of the direct support program. Ideally, the given six months receiving phase for direct support before evaluation is done to make sure recipient households work hard to graduate. Table 6 indicates that $40.9 \%$ of households strongly disagreed with the statement, $33.1 \%$ normally disagreed and $20.4 \%$ were not sure while only $2 \%$ and $3.2 \%$ respectively were normally agreed and strongly agreed with the statement showing that it is an effective mechanism.

This means that they need more time for receiving these supports before being evaluated. That is why initially, the leaders had mentioned that the majority of the households fail to graduate because they like receiving every month for an extended period rather than utilizing this money to improve their livelihood. 
Table 7: Respondents views on the six months evaluation period

\begin{tabular}{cll}
\hline $\begin{array}{l}\text { Six months } \\
\text { evaluation period }\end{array}$ & Frequency & $\%$ \\
\hline Valid Strongly agree & 240 & 98.3 \\
Agree & 2 & 0.8 \\
Disagree & 0 & 0 \\
$\begin{array}{l}\text { Strongly } \\
\text { Disagree }\end{array}$ & 0 & 0 \\
Not sure & 2 & 0.8 \\
Total & 244 & 100 \\
\hline
\end{tabular}

The table 7 above shows that $98.3 \%$ strongly agreed with the statement, $0.8 \%$ agreed and $0.8 \%$ mentioned that they are not sure whether the prior of six months payment duration is not enough to access the graduation of the household. This emphasizes the dissatisfaction of the households on the time given for them to be evaluated to the next stage. While asked to identify any problem they find in the payment process of direct support transfer earning if any, they cited that the living standard has gone up and the amount they receive as direct support is quite small. They mentioned that the amount cannot be able to meet their basic need such as paying house rent, buying food, clothing and even paying a medical bill for some of them because others are supposed to be paid by the government.

Table 8: Relationship between the beneficiary and socio-economic development

\begin{tabular}{lccl}
\hline Value & & df & $\begin{array}{l}\text { Asymp. Sig. (2- } \\
\text { sided) }\end{array}$ \\
\hline $\begin{array}{l}\text { Pearson Chi- } \\
\text { Square }\end{array}$ & $11.786^{\mathrm{a}}$ & 2 & .003 \\
$\begin{array}{l}\text { Likelihood } \\
\text { Ratio }\end{array}$ & & 2 & .001 \\
$\begin{array}{l}\text { Linear-by- } \\
\text { Linear }\end{array}$ & 14.048 & & \\
$\begin{array}{l}\text { Association } \\
\mathrm{N} \text { of Valid }\end{array}$ & 10.584 & 2 & .001 \\
Cases & & & \\
\hline
\end{tabular}

4 cells gave an expected count less than 5 . The minimum expected count is 39 .

The study found that there is a significant correlation between the processes of households' ability to engage in economic activities. This is indicated by a Pearson Chi-square value of $11.786^{\mathrm{a}}$ and a $\mathrm{p}$-value of .003. This value is less than 0.005 alpha which is a standard measure to accept the relationship between households' selection process and their socioeconomic development.

Table 9: Crosstab between process and engagement in socio-economic activities

\begin{tabular}{lllll}
\hline $\begin{array}{l}\text { Asset } \\
\text { buying }\end{array}$ & Disagree & $\begin{array}{l}\text { Not } \\
\text { sure }\end{array}$ & Agree & $\begin{array}{l}\text { Strongly } \\
\text { agree }\end{array}$ \\
\hline Yes & 2 & 5 & 180 & 50 \\
No & 0 & 0 & 2 & 5 \\
Total & 2 & 5 & 182 & 52 \\
\hline
\end{tabular}

Table 9 presents the correlation of two variables which shows the relationship between the respondents who stated that they receive direct support funds on a regular monthly basis and their response on what they highly rate that they use the money to do asset buying to establish if there is a statistically significant difference between this two variables. The information below shows the chisquare test values observed in this test.

Table 10: Monthly receipt and asset development

\begin{tabular}{llll}
\hline Value & & df & $\begin{array}{l}\text { Asymp. Sig. (2- } \\
\text { sided) }\end{array}$ \\
\hline $\begin{array}{l}\text { Pearson } \\
\begin{array}{l}\text { Chi-Square } \\
\text { Likelihood }\end{array}\end{array}$ & $52.633^{\mathrm{a}}$ & 3 & .000 \\
$\begin{array}{l}\text { Ratio } \\
\text { Linear-by- }\end{array}$ & 15.716 & 1 & .000 \\
$\begin{array}{l}\text { Linear } \\
\begin{array}{l}\text { Association } \\
\mathrm{N} \text { of Valid }\end{array}\end{array}$ & 244 & & .000 \\
Cases & & & \\
\hline
\end{tabular}

4 cells $(50 \%)$ gave the expected count less than 5. The minimum expected count is 52. Table 10 indicates that there is a strong correlation between this variables because the p-value is less than 0.05 which indicated that indeed there is a statistically significant relationship between monthly receives of direct support program package in terms of cash and households ability to buy assets for themselves. This is indicated by a p-value of .000 and a Pearson ChiSquare value of $52.633 \mathrm{a}$.

The study wanted to find out whether they are any effects as a result of households training on various entrepreneurial skills which may help them to be economically productive. The information in the tables below shows the results of the problem.

Table 11: Respondents views on the training

\begin{tabular}{|c|c|c|c|}
\hline \multicolumn{3}{|c|}{ Training skills on Frequenc } & $\%$ \\
\hline \multirow[t]{6}{*}{$\begin{array}{l}\text { Vali } \\
\text { d }\end{array}$} & $\begin{array}{l}\text { Strongly } \\
\text { agree }\end{array}$ & 188 & 77 \\
\hline & Agree & 56 & 23 \\
\hline & Disagree & 0 & 0 \\
\hline & $\begin{array}{l}\text { Strongly } \\
\text { Disagree }\end{array}$ & 0 & 0 \\
\hline & Not sure & 0 & 0 \\
\hline & Total & 244 & 100 \\
\hline
\end{tabular}


While seeking to find out the effect of households training and access to credit on economic productivity, the researcher found in table 11 that $77 \%$ the respondents strongly believe that the tailored training meant for direct support households have enabled them to acquire skills related to the field of economic activity thus increasing ability to be self-reliant and $23 \%$ have normally agreed with the statement. This means that the acquired training skills were highly affected positively the households to sustain their productivity in their family.

Table 12: Respondents views on the direct transfer earnings

\begin{tabular}{|c|c|c|}
\hline $\begin{array}{l}\text { Direct support, } \\
\text { training and loans }\end{array}$ & Frequency & $\%$ \\
\hline Vali Strongly agree & 201 & 82.3 \\
\hline Agree & 34 & 13.9 \\
\hline Disagree & 5 & 2 \\
\hline $\begin{array}{l}\text { Strongly } \\
\text { Disagree }\end{array}$ & 0 & 0 \\
\hline Not sure & 4 & 1.6 \\
\hline Total & 244 & 100 \\
\hline
\end{tabular}

The results in table 12 that $82.3 \%$ of the respondents strongly agreed with the statement, $13.9 \%$ normally agreed with the statement that direct transfer earning are combined with training and small loans access as an additional intervention for their social-economic sustainability. Households indicated that they get training on financial planning and management, farming and also entrepreneurial skills.

Table 13: Relationship between direct support project and socio-economic activities

\begin{tabular}{llll}
\hline Value & & df & $\begin{array}{l}\text { Asymp. Sig. (2- } \\
\text { sided) }\end{array}$ \\
\hline $\begin{array}{l}\text { Pearson } \\
\text { Chi-Square }\end{array}$ & $20.505^{\mathrm{a}}$ & 3 & .000 \\
$\begin{array}{l}\text { Likelihood } \\
\text { Ratio }\end{array}$ & 35.665 & 3 & .000 \\
$\begin{array}{l}\text { Linear-by- } \\
\text { Linear }\end{array}$ & 21.439 & 1 & .000 \\
$\begin{array}{l}\text { Association } \\
\text { N of Valid }\end{array}$ & 244 & & \\
Cases & & & \\
\hline
\end{tabular}

4 cells gave an expected count less than 5 . The minimum expected count is 3.13 .

The correlation indicated that there is as a statistically significant relationship between the direct support program and social-economic development of the households because the p-value of these correlations is less than 0.05 . This means we adopt the alternate hypothesis and reject the null. The Pearson Chi-Square is 26.505a and the level of significance is .000 which indicates strong correlations.

\subsection{Discussion}

The researcher discussed themes related to research objectives such as to assess the process of selecting direct support for the households and its effect on socio-economic development of lowincome earners, to investigate the economic activities that households undertake through Direct support for economic productivity and self-reliance, assess the payment process and duration of delivery of Direct support funds and how it affects recipient households' productivity and sustainability, and to assess the payment process and duration of delivery of Direct support funds and how it affects recipient households' productivity and sustainability.

Findings of this research were drawn from 244 respondents and have contributed to filling research questionnaire. To achieve this, research questions were grouped based on research objectives. Social demographic characteristics of respondents were based on a different group of age; marital status, gender, experience and academic background.

The study established that $98.3 \%$ strongly agreed that Ubudehe process is both used in the identification of target households for direct support in the sector (Umurenge). Under the Program, households are put in categories based on their social-economic status, and their property in terms of land and other belongings and what the families' breadwinners do to earn a living. The categories are as follows:

Category 1: Families who do not own a house and can hardly afford basic needs.

Category 2: Those who have a dwelling of their own or can rent one but rarely get full-time jobs.

Category 3: Those who have a job and farmers who go beyond subsistence farming to produce a surplus which can be sold. The latter also includes those with small and medium enterprises who can employ dozens of people.

Category 4: Those who own large-scale business, individuals working with international organisations and industries as well as public servants.

The new Ubudehe categorisation process involves local leaders and communities. The community gathers and a representative from each household gives details on the families' social and economic status. The details are provided through to a questionnaire designed by the Ministry of Local Government. After each household has filled in the questionnaire, the community gathers at the cell level to crosscheck the accuracy of the information. When the community approves the information as accurate, the categorisation process begins. All the members who are eligible for direct support households are adults above 18 years incapable of manual labour. 
The study established that since this Program targets poor people in the society, majority of the households seems to be reluctant to struggle hard to graduate to other higher levels where they can sustain themselves without direct support. However, the study revealed that $63.5 \%$ of the households strongly agreed that leaders' rankings are the transparent and reliable way of identifying the right targets for direct support intervention.

The study established that $100 \%$ of households stated that direct support Program has enabled them to undertake to subsist business which enables them to buy food and supplies, $94.6 \%$ stated that direct support Program has enabled them to buy assets, $59.4 \%$ mentioned that they can buy medication, for instance, paying for medical insurance and drugs, $45.4 \%$ of them stated that they have been able to pay school fees, $37.2 \%$ have been able to improve their lives by acquiring assets by buying animals like goats, chicken and pigs using the direct support Program, $44.2 \%$ indicated that they have been able to join cooperatives where they contribute money for savings and another $4 \%$ highlighted the have been able to conduct other economic activities such as selling water, fruits, vegetables and so on.

It was indicated that the households receive direct support funds on a regular monthly basis and is considered to be reliable. The payments are made directly to bank accounts and never receive cash by hand. This implies that they must have a bank account once they are registered in this Program. There are incentives such as additional grants given as a way to encourage maximum savings by direct support households in the sector.

However, the study found out that the households do not agree that the mechanism used to evaluate the households to enable them to graduate to different levels of the direct support program is effective. Ideally, they were given six months receiving phase for direct support before evaluations are done to make sure recipient households work hard to graduate. On the other hand, the majority of households fail to graduate because they like receiving every month for an extended period rather than utilizing this money to improve their livelihood. The study found out that $98.3 \%$ of the households strongly agreed the prior six-monthly payment duration is not sufficient to assess the graduation of households. This emphasizes the dissatisfaction of the households on the time given for them to be evaluated to the next stage. They complained that the living standard has gone up and the amount they receive as direct support is quite small.

While seeking to find out the effect of households training and access to credit on economic productivity, the researcher found out that $77 \%$ of the respondents strongly believe that the tailored pieces of training meant for direct support households have enabled households to acquire skills related to the field of economic activity. Households indicated that they get training on financial planning and management, farming and also entrepreneurial skills.

\section{Conclusions and Recommendations}

The study found that there is a statistically significant relationship between monthly receives of direct support program package in terms of cash and households ability to buy assets for themselves.

The study found that there is a statistically significant relationship between beneficiary's ability to receive direct support funds on a regular monthly basis and respondent's access to medical services such as (paying for medical Insurance, Drug, etc).

The correlation also indicated that there is as a statistically significant relationship between the direct support program and social-economic development of the households. The study indicated that when beneficiary received direct support funds on a regular monthly basis, they can buy an animal for rearing such as goats, pigs and cows so that they can be able to sell them in them with a profit or consume their products such like milk.

Direct support Program focuses on moving people out of the extreme poverty in a shorter term. However, to move people out of the poverty in a sustainable process, poor people are required to use whatever means either assets or talents into income and increase their production capacity Cash transfer constitutes an effective mechanism for providing a resource to the poor households if the essential goods are available at the market but the poor do not have money to purchase them. If the amount of the transfer is enough to cover the expenditure deficits and it is predictable, a cash transfer can also provide a solid base to reduce poverty by encouraging households to develop their skills and take risks and adopt other livelihood support activities.

The poor and extremely poor and extremely poor households require an integrated approach that combines activities in a way that addresses their needs. The direct support cash transfer is based on the rationale that many of the poorest can be helped to help themselves meet the survival and livelihood survival needs and some will have the potential to eventually graduate out of the poverty if given the right support.

The study recommends that there are issues which need to be addressed to improve the effectiveness of this Program.

i. Evaluation time needs to be increased to allow the households enough time to graduate. Table 4.15 shows that majority of the respondents indicated that prior six-monthly payment duration is not sufficient to assess the graduation of households.

ii. The other recommendation is to increase the amount of payment given to the households to 
improve their living standard. They mentioned that the amount cannot be able to meet their basic needs such as paying house rent, buying food, clothing and even paying medication bills. The amount provided is less as compared to the needs and therefore there is a need to increase the amount of direct support funding.

iii. Training Program needs to be structured such that it provides relevant skills to households' particularly financial management skills and saving. This is because the majority of the households are semi-illiterate and therefore do not have such vital skills.

\section{Appendix}

\section{Research questionnaire}

Respondent's profile

Kindly tick $(\sqrt{ })$ on the appropriate for you

1. Respondent's Gender
a) Male
[ ]
b) Female
2. Respondent's age
a) $18-25$
b) $26-35$
c) $36-45$
d) 46 and above

3. Respondent's educational level attained
a) University
b) Secondary
c) Primary
[]
d) Trainings
e) None
$[1]$
[]
[]

Use the Likert scale provided to rate your degree of agreement or disagreement with the following statement regarding the process of direct support beneficiary identification.

$1=$ strongly disagree $2=$ Disagree $3=$ Not sure $4=$ Agree $5=$ Strongly Agree

\section{Research Question 1}

The process of direct support beneficiary identification

a) The 'ubudehe' process is both used in the identification of target Households for direct support in the sector (Umurenge).

12345

b) The JDAF committee rankings are the transparent and reliable way of identifying the right targets for direct support intervention

12345

c) The registration of the head of the household member as a representative of all members for an identified household is a good practice.

12345

d) What reasons in your view, have led to the failure of some direct support recipient households from graduating and achieving self-sustainability?

\section{Research question 2}

What sort of economic activities do direct support Households undertake for self-economic when they receive direct support funds?

a) From the box below, tick the activities that you engage in for your household economic using direct support funds.

\begin{tabular}{|l|l|}
\hline Activities & $\begin{array}{l}\text { TICK () Where } \\
\text { applicable }\end{array}$ \\
\hline $\begin{array}{l}\text { 1.Subsistence (buying food + } \\
\text { supplies) }\end{array}$ & \\
\hline 2. Mutuelle de Sante & \\
\hline $\begin{array}{l}\text { 3. Fruits and vegetable (sales } \\
\text { grocery) }\end{array}$ & \\
\hline 4. Asset buying & \\
\hline 5. Cooperative (saving) & \\
\hline 6. Loan re-servicing & \\
\hline $\begin{array}{l}\text { 7. Animal rearing (goats and } \\
\text { pigs) }\end{array}$ & \\
\hline 8. School fees & \\
\hline 9. Water sale & \\
\hline 10. Others (specify) & \\
\hline Research question 3 & \\
\hline
\end{tabular}

Research question 3

How does the payment and delivery process of funds affect the Households' economic productivity?

Use the Likert scale provided to indicate your degree of agreement or disagreement with the statements below

$1=$ strongly disagree $2=$ Disagree $3=$ Not sure $4=$ Agree $5=$ Strongly Agree

a) The beneficiary received direct support funds on a regular monthly basis

12345

b) The process and duration for the reception of direct support funds are predictable and reliable.

\section{5}

c) Payments are made directly to bank accounts and never received cash by hand

\section{5}

d) There are incentives such as additional grants given as a way to encourage maximum savings by direct support households in the sector.

\section{5}

e) The six-monthly receiving phase for direct support before evaluations is an effective mechanism to make sure recipient households work hard to graduate

\section{5}

f) The prior six-monthly payment duration is not sufficient to assess the graduation of households 12345 
g) Identify any problems that you find in the payment process of direct support transfer earnings if any.

h) Explain how these problems affect household economic productivity?

\section{Research question 4}

In what ways do Households training and access to credit affect their economic productivity?

Use the Likert scale provided to indicate your degree of agreement or disagreement with the statements below

$1=$ strongly disagree $2=$ Disagree $3=$ Not sure $4=$ Agree 5 = Strongly Agree

a) The tailored pieces of training to direct support transfer earnings have enabled Households to acquire skills related to the field of economic activity thus increasing the ability to be self-reliant.

12345

b) From the sensitizations and pieces of training, household obligations for households that are recipients of direct support are clear.

12345

c) Identify at least 3 skills related to what you economically do that you have acquired as a result of the tailored pieces of training and sensitizations to direct transfer earnings.

\section{Acknowledgments}

The researchers would, first, wish to extend their heartfelt sincere thanks to many of their colleagues at Mount Kenya University for the constructive ideas. Last but not least, the same thanks are extended to all those, who materially or morally, contributed to my success. Population of Mwendo Sector for their kind co operations to the research through the questionnaire. And last but not least, their deep thanks

would go to IJASRM journal board for this paper to be published to the public, especially those interested in socio-economic development of rural population.

\section{References}

[1] Ayako, B. (2006, February 10). Lessons of the Experience with Direct Support to School Mechanism. Synthesis. Retrieved March 20, 2019, from http://www.adeanet.org.

[2] Brasil, A. V. (2013). CCPM turning the invisible into visible for decisions, TOCICO International Conference: 11th Annual Worldwide Gathering of TOC Professionals, Bad Nauheim, Germany, Theory of Constraints International Certification Organization.

[3] Castelloe, G. N. (2002). Thematic Evaluation on Poverty Reduction / Community Development: Macmillan Press Ltd, Hound Mills.

[4] Collier, P. (2007). The Bottom Billion: Why the Poorest Countries Are Failing and What Can Be Done About It? New York, New York 10016: Oxford University Press, Inc. 198 Madison Avenue.

[5] Ladzani, W., \& Netswera, G. (2009). Support for rural small businesses in Limpopo province: South Africa, Development Southern Africa, Vol. 26, No. 2.

[6] Mensah, S. N. A., \& Benedict, E. (2009). Entrepreneurship training and poverty alleviation: Empowering the poor in the eastern Free State of South Africa: African Journal of Economic and Management Studies, Vol. 1, No. 2.

[7] Mutezo, A. (2005). Obstacles in the access to SMME finance: An empirical perspective on Tshwane: Unpublished Master's Thesis, University of South Africa, Pretoria.

[8] Turner, J. R., \& Müller, R. (2003). On the Nature of a Project as a Temporary Organization: International Journal of Project Management, vol. 21, 1-8.

[9] VUP, (2011). Social protection Programs reduce extreme poverty in targeted VUP sectors: Vision 2020 Umurenge Programme. Kigali.

[10] VUP. (2010). Economic Development \& Poverty Reduction Strategy 2008 - 2012: Vision 2020 Umurenge Program (VUP) - Baseline Survey. Kigali.

[11]MINALOC. (2008). Poverty Analysis of Ubudehe, Republic of Rwanda: Community

[12] MINALOC. (2009). Vision 2020 Umurenge Programme (VUP). Direct Support Operational Framework and Procedure Manual. Kigali. Revised Version. Retrieved March 20, 2019, from http://nyamagabe.gov.rw/fileadmin/user_upload/ Direct_Support_manual_v_200209_incl__anne xes.pdf

[13]NISR. (2015). Rwanda Integrated Household Living Conditions Survey. Social protection and VUP report. Kigali. Results of EICV 4 
[14]Brandt, W. (2006). World Poverty. The Brandt Report: A Summary. Revised Version. Retrieved March 20, 2019, from https://www.sharing.org/informationcentre/reports/brandt-report-summary

[15] Maslow, A. (1970). Motivation and personality (2nd ed.). New York: Harper \& Row.

[16]Besley, T., \& Kanbur, R. (1991). Current Issues in Development Economics: The Principles of Targeting. Springer. Retrieved March 20, 2019, from https://link.springer.com/chapter/10.1007/978-1349-21587-4_5

[17]Besley, T. and Coate, S. (1997). An economic model of representative democracy. Quarterly Journal of Economics 112: 85-114.

[18]Hansen, W. L., Kelley, A. C., and Weisbrod, B. A. (1970). Economic Efficiency and the Distribution of Benefits from College Instruction. American Economic Review, 1970, vol. 60 , issue 2, 364-69.

[19]Henrich, J., Boyd, R., Bowles, S., and Camerer, C. (2005). Economic man" in cross-cultural perspective: Behavioral experiments in 15 small-scale societies. DOI: https://doi.org/10.1017/S0140525X05000142. Published online by Cambridge University Press.

[20] Todaro, M. P. (2005). Economic Development in the Third World. Longman, New York.

[21] The Economist (2013). A hopeful continent. Emerging Africa. Special Report. Retrieved March 20, 2019, from https://www.economist.com/sites/default/files/2 0130203_emerging_africa.pdf

[22] Deininger, K., \& Okidi, J. (2001). Growth and poverty reduction in Uganda, 1999-2000: Panel data evidence. Development policy review 21 (4), 481-509.

[23] Abor, J. \& Quartey, P. (2010). Issues in SME development in Ghana and South Africa. International Research Journal of Finance and Economics 39:218-228.

[24]GOR, (2007). Rwanda's Vision 2020: Pillars and cross cutting areas. MINECOFIN. Kigali.

[25] Austin, M., Chow, J., Hastings, J., Taylor, S., Johnson, M., Leer, E., \& Lemon, K. (2004). Serving Low-income Families in Poverty Neighborhoods Using Promising Programs and Practices: Building a Foundation for Redesigning Public and Nonprofit Social Services. Retrieved December 7, 2019, from https://www.researchgate.net/profile/Julian_Cho w2/publication/7354548_The_status_of_low- income_neighborhoods_in_the_post-

welfare_reform_environment_mapping_the_rela tionship_between_poverty_and_place/links/557 0731108aee1eea7587a49/The-status-of-lowincome-neighborhoods-in-the-post-welfarereform-environment-mapping-the-relationshipbetween-poverty-and-place.pdf

[26]Zedlewski, S. R., Nelson, S., Edin, K. Koball, H., Pomper, K., 奋oberts, T. (2003). Families Coping without Earnings or Government Cash Assistance. Urban Institute. Assessing the New Federalism Occasional Paper No. 64.

[27]Burns, N., \& Groves, K. (1997). Practice of nursing research. Just.edu.jo. Retrieved December 7, 2019, from https://scholar.google.com/scholar?lookup=0\&q =Burns+Grove+1997\&hl=en\&as_sdt=0,5\&as_vi $\mathrm{s}=1$.

[28] Grinnell, R. M. \& Williams, M. (1990). Research in social work: A primer. Itasca, IL: F. E. Peacock, pp. 139-176.

[29] Golafshani, N. (2003). Understanding Reliability and Validity in Qualitative Research. University of Toronto. Retrieved December 7, 2019,

from https://nsuworks.nova.edu/tqr/vol8/iss4/6/

[30]Barungi, F. (2017). Contribution of Business Development Fund to the Financial Access by Small and Medium Enterprises in Rwanda. A Dissertation submitted to the School of Business, College of Business and Economics in partial fulfillment of the requirements for the award of Master of Business Administration of the University of Rwanda. University of Rwanda.

[31] Mujawase, F. (2017). The Impact of Vision2020 Umurenge program (VUP) on child well-being in Rwanda. Retrieved December 7, 2019, from https://www.academia.edu/35698797/title_the_i mpact_of_vision2020_umurenge_program_vup_ on_child_well-being_in_rwanda.

[32] Mpayimana E. (2016). Vision 2020 Umurenge Programme and Poverty Reduction in Rwanda: a Case Study of Nyarubaka sector. A Thesis Submitted in partial fulfillment of the requirements for the award of Master"s Degree in Business Administration. University of Rwanda.

[33] Mpambara, F., \& Umutoni, B. (2015). The Effect of Credit Packages of Vision 2020 Umurenge Programme in Poverty Alleviation in Rulindo District. East African Journal of Science and Technology, Vol.5. 